\title{
In vitro establishment of blackberry (Rubus sp.) cultivar 'Xavante'
}

\author{
Estabelecimento in vitro de amoreira preta (Rubus sp.) cultivar 'Xavante'
}

\author{
Tânia Regina Pelizza ${ }^{I}$ Fabiane Nunes Silveira ${ }^{\text {II }}$ Roberta Sabatino Ribeiro III \\ Bruno Dalazen Machado ${ }^{I I}$ Leo Rufatto ${ }^{\text {IV }}$ Aike Anneliese Kretzschmar ${ }^{\text {IV }}$
}

- NOTE -

\section{ABSTRACT}

The objective of this study was to evaluate the in vitro establishment of 'Xavante' blackberry under different conditions of plant luminosity and concentrations of salts of MS medium. The maintenance of 'Xavante' blackberry plants in the absence of light, with the use of MS medium with salt concentrations of $75 \%$ and $100 \%$ reduce bacterial contamination and the percentage of explants oxidized and provide the highest percentage of surviving and established explants. The 50\% salt dilution in MS medium is not recommended when plants are subjected to the absence of light due to the high percentage of oxidized explants and consequently lower survival and establishment.

Key words: contamination, luminosity, in vitro maintenance, micropropagation, oxidation.

\section{RESUMO}

Oobjetivo deste trabalho foi avaliar o estabelecimento in vitro de amoreira preta 'Xavante' sob diferentes condições de luminosidade da planta matriz e concentrações de sais do meio MS. A manutenção de plantas matrizes de amoreira preta 'Xavante' na ausência de luz, com a utilização de meio MS nas concentrações de $75 \%$ e $100 \%$ dos sais, reduzem a contaminação bacteriana e o percentual de explantes oxidados e proporcionam maior percentual de sobrevivência e explantes estabelecidos. Não se recomenda a diluição do meio MS para $50 \%$ dos sais quando as plantas forem submetidas à ausência de luz, devido ao alto percentual de explantes oxidados e, consequentemente, baixa sobrevivencia e estabelecimento.

Palavras-chave: contaminação, luminosidade, manutenção in vitro, micropropagação, oxidação.
Micropropagation is considered the main tissue culture technique, in terms of practical potential use in agriculture, producing seedlings with genetic characteristics identical to the mother plant and with high genetic quality (VILLA et al., 2008). The MS medium (MURASHIGE e SKOOG, 1962) is the most widely used for the propagation of several species, however, its concentration of nutrients has been identified as high (PIERIK, 1987).

The condition to which the mother plant is submitted to is another aspect to be considered. According to GRATTAPAGLIA \& MACHADO (1998), plants kept under full light, woody species in particular, synthesize a higher amount of phenolic compounds, which causes explant damage and in vitro oxidation. Thus, the maintenance of mother plants in the absence of light could reduce the percentage of explant oxidation and consequently enable us to obtain a greater number of established explants. The objetive of this research was to evaluate the in vitro establishment of 'Xavante' blackberry under different conditions of mother plant luminosity and different concentrations of MS medium salts.

The experiment was carried out at the Laboratory of Plant Micropropagation at the Universidade do Estado de Santa Catarina (UDESC/ $\mathrm{CAV}$ ), in the city of Lages (SC - Brazil). The mother plants of 'Xavante' blackberry were seven months

\footnotetext{
'Universidade Federal da Fronteira Sul (UFFS), Campus Chapecó, Km 02, 89801-001, Chapecó, SC, Brasil. E-mail: tania.pelizza@uffs.edu.br. Corresponding author.

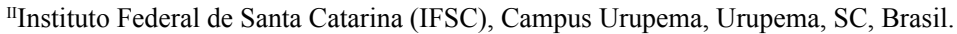

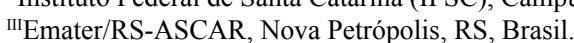

${ }^{\mathrm{IV}}$ Centro de Ciências Agroveterinárias (CAV), Universidade do Estado de Santa Catarina (UDESC), Lages, SC, Brasil.
} 
old and were stored in a growth chamber under a temperature of $25^{\circ} \mathrm{C}$ and a $75 \%$ relative air humidity. Herbaceous stem cuttings were collected from those and generated nodal stem segments (explants) with $1.5 \mathrm{~cm}$ of length. xplants were washed with detergent and running water. The disinfection was performed with $70 \%$ ethanol for one minute, followed by $2.5 \%$ sodium hypochlorite containing 3 added drops of Tween 20 for 12 minutes, followed by five washes with sterile distilled water.

The explants were stored in a growth room, in the absence of light for seven days in order to reduce their oxidation and then inoculated in a culture medium. After that, they were kept under a $\pm 25^{\circ} \mathrm{C}$ controlled temperature, with a photoperiod of 16 hours of light and $30 \mu \mathrm{mol} \mathrm{m} \mathrm{m}^{-2} \mathrm{~s}^{-1}$ of light incidence that was obtained with cool white fluorescent lamps. The culture medium used was MS medium supplemented with $30 \mathrm{~g} \mathrm{~L}^{-1}$ of sucrose and $6.5 \mathrm{~g}$ of agar, without the use of any phyto regulator. The $\mathrm{pH}$ of the culture medium was adjusted to 5.0 before autoclaving.

The experimental design was completely randomized in a $2 \times 3$ factorial arrangement, with two conditions of mother plant maintenance: presence or absence of light (plants submitted to the absence of light were kept in the dark for twenty days before the propagation material was collected) and three concentrations of salts of the MS medium (100, 75 and 50\%) with four replications, each being composed by six test tubes containing one explant. After 30 days of in vitro culture, the percentage of explants with fungal and bacterial contamination, oxidized, as well as surviving and established was assessed. A surviving explant was considered to be the explant that did not present in vitro oxidation and the established was the explant that showed shoots. After the analysis of variance, a comparison of the means was carried out with a Tukey test $(\mathrm{P}<0.05)$.

Smaller percentages of bacterial contamination were observed when plants were kept in the absence of light and when the MS medium was used with salt concentrations of $75 \%$ and $100 \%$. For the same variable, no influence of the medium concentrations was observed when the plants were continuously maintained in the presence of light (Table 1). In a study carried out by SOUZA et al. (2006) with the in vitro establishment of Psidium cattleyanum (cv. 'Irapuã') in a MS medium plus $5 \mu \mathrm{M}$ of BAP, mother plants were kept in the presence and absence of light for 15 days and then evaluated, their results showed that a higher bacterial contamination was found in the explants that were submitted to the presence of light.
It is worth mentioning that, in this study, the bacterial contamination detected in the explants was caused by the presence of endophytic bacteria, that is, they were internally present in the actual explants. Regarding the fungal contamination of the explants, none was found in any of the tested treatments.

The explants originated from mother plants that were submitted to the absence of light in $75 \%$ salt concentration of MS medium did not show oxidation. In this same condition, no significant difference was observed between the aforementioned concentration and $100 \%$ of salt of MS medium. When the mother plants were submitted to the incidence of continuous light, the lowest percentage of oxidized explants was reported in the $100 \%$ concentration of MS medium (Table1). RODRIGUES et al. (2003) observed that, in the in vitro establishment of Prunus sp. with the use of terminal bud taken from mother plants that were submitted to continuous light incidence, the lowest percentage of oxidized explants $(3.7 \%)$ was obtained with the use of $\mathrm{V}$ medium in comparison to MS medium. According to the authors the $\mathrm{V}$ medium presents a lower concentration of salts than MS medium. In this study; however, the MS nutrient medium with $100 \%$ of salts, in the condition where the mother plants were submitted to continuous light incidence, determined a lower percentage of oxidized explants. It is noteworthy that these results were obtained specifically for the cultivar of 'Xavante' blackberry and should not be extrapolated to the Rubus genus.

The nodal segments taken from mother plants of 'Xavante' blackberry, which were submitted to the absence of light in a nutrient medium with $50 \%$ of salt concentration, were noticed to be tender and whitened during the development of this research. This is probably because they were more sensitive to the absence of salts in the nutrient medium; this consequently allowed to observe a higher percentage of oxidized explants in comparison to the other concentrations of salts, which inhibited their establishment, since the culture medium should supply the plant tissues and organs with nutrients essential for growth, when cultured in vitro conditions.

Furthermore, when comparing the variables of bacterial contamination and oxidation of explants in the condition of absence of light, there seems to be a close link between them. It is believed that along with a high oxidation of the explants, caused by the absence of light and small concentration of salts in the medium, there is a tendency for the plant tissue of the explants to manifest an endophytic bacterial contamination. 
Table 1 - Explants percentage of 'Xavante' blackberry with bacterial contamination, oxidized, surviving and established sobbing two brightness conditions of the mother plant and the concentrations of MS medium salts. CAV/UDESC, Lages (SC) (2013).

\begin{tabular}{|c|c|c|c|c|}
\hline & \multicolumn{2}{|c|}{ 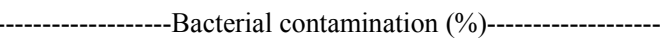 } & \multicolumn{2}{|c|}{ 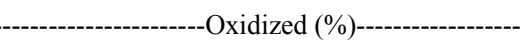 } \\
\hline & Presence of light & Absence of light & Presence of light & Absence of light \\
\hline MS $50 \%$ & $66.7 \mathrm{Aa}^{*}$ & 79.2 Aa & $58.3 \mathrm{Ab}$ & $95.8 \mathrm{Aa}$ \\
\hline MS $75 \%$ & $66.7 \mathrm{Aa}$ & $12.5 \mathrm{Bb}$ & $62.5 \mathrm{Aa}$ & $0.0 \mathrm{Bb}$ \\
\hline MS $100 \%$ & 75.0 Aa & $12.5 \mathrm{Bb}$ & $20.8 \mathrm{Ba}$ & 4.2 $\mathrm{Ba}$ \\
\hline CV $(\%)$ & \multicolumn{2}{|c|}{21.6} & \multicolumn{2}{|c|}{32.3} \\
\hline \multirow[t]{3}{*}{$\mathrm{P}$} & \multicolumn{2}{|c|}{$<0.01$} & \multicolumn{2}{|c|}{$<0.01$} \\
\hline & 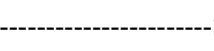 & 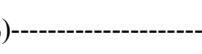 & -Es & (\%)--------------- \\
\hline & Presence of light & Absence of light & Presence of light & Absence of light \\
\hline MS $50 \%$ & 41.7 Aa & $0.0 \mathrm{Bb}$ & $37.5 \mathrm{Aa}$ & $0.0 \mathrm{Cb}$ \\
\hline MS $75 \%$ & $33.3 \mathrm{Ab}$ & $91.7 \mathrm{Aa}$ & $33.3 \mathrm{Ab}$ & $91.7 \mathrm{Aa}$ \\
\hline MS $100 \%$ & $54.2 \mathrm{Ab}$ & $87.5 \mathrm{Aa}$ & $54.2 \mathrm{Aa}$ & $66.7 \mathrm{Ba}$ \\
\hline CV (\%) & \multicolumn{2}{|c|}{25.00} & \multicolumn{2}{|c|}{23.00} \\
\hline $\mathrm{P}$ & \multicolumn{2}{|c|}{$<0.01$} & \multicolumn{2}{|c|}{$<0.01$} \\
\hline
\end{tabular}

${ }^{*}$ Means followed by the same lower case letter in the line and capital letter in the column do not differ between each other according to the Tukey test at a 5\% error probability.

${ }^{* *}$ Surviving explant: explant that did not present in vitro oxidation. Established explant: explant that presented shoots.

In this study $41.7 \%$ of the surviving explants were obtained from mother plants that were submitted to the incidence of continuous light and in the concentration of $50 \%$ of salt of MS medium. Explants derived from mother plants submitted to the absence of light presented a higher survival percentage when the MS medium concentration of salts was $75 \%$ and $100 \%$. In this same condition of mother plant, but with a $50 \%$ of salt concentration, no surviving explants were observed (Table 1). ASSIS et al. (2012) observed a higher survival percentage in the in vitro establishment of Anacardium othonianum with the use of total and intermediate concentrations of WPM culture medium (100 and $50 \%$ ). SOUZA et al. (2006) noticed a higher survival percentage of Psidium cattleyanum (cv. 'Irapuã') in mother plants that were submitted to a regimen of absence of light. BIASI (1996) states that excellent results are obtained when etiolation is used as a pretreatment in mother plants of fruit species that present difficult regeneration. However, in the conditions in which this study was conducted, the submission to etiolation, through the absence of light on mother plants of 'Xavante' blackberry, profoundly affected the survival of explants when these were established in a nutrient medium composed of salts reduction (50\%) in comparison to a nutrient medium with whole or $75 \%$ of salts concentration.
The highest percentage of established explants was approximately $91.7 \%$ when mother plants were maintained in the absence of light and the medium used was $75 \%$ (Table1). RODRIGUES et al. (2003), when evaluating the in vitro establishment of Prunus sp., with $75 \%$ and $100 \%$ of salt concentrations of MS medium, observed a higher percentage of established explants at the concentration of $75 \%$. In the condition of absence of light it was possible to verify that the explants of 'Xavante' blackberry established in MS medium with $50 \%$ of salt concentration did not present surviving nor established explants, as well as a higher percentage of oxidized explants and explants with bacterial contamination.

According to DZAZIO et al. (2002) in a research carried out with ' 420 -a' grapevine rootstock, $80 \%$ of the nodal segments were lost due to contamination and oxidation, when the MS/8 nutrient medium was used, probably due to a reduced concentration of salts.

The maintenance of 'Xavante' blackberry mother plants in the absence of light, with the use of MS medium and salt concentration of $75 \%$ and $100 \%$, reduce the bacterial contamination and the percentual of oxidated explants and provided a greater percentual of surviving and established explants. The dilution of the MS medium to a salt 
concentration of $50 \%$ is not recommended when the plants are submitted to the absence of light.

\section{AKNOWLEDGEMENTS}

The authors would like to thank Coordenação de Aperfeiçoamento de Pessoal de Nível Superior (CAPES) for the financial support to the project.

\section{REFERENCES}

ASSIS, K.C. de et al. In vitro cultivation of Anacardium othonianum Rizz.: effects of salt concentration and culture medium volume. Acta Scientiarum Agronomy, Maringá, v.34, n.1, p.77-83, 2012. Available from: <http://www.scielo.br/scielo. php?pid $=$ S1807-86212012000100011\&script $=$ sci_arttext $>$. Accessed: Apr. 12, 2013. doi: 10.4025/actasciagron.v34i1.10984.

BIASI, L.A. Etiolation to clonal plant propagation. Ciência Rural, Santa Maria, v.26, n.2, p.309-314, 1996. Available from: $<$ http://www. scielo.br/scielo.php?pid=S0103-84781996000200025\&script $=$ sci arttext>. Accessed: Dec. 15, 2012. doi: 10.1590/S010384781996000200025 .

DZAZIO, P.M. et al. Micropropagation of '420-A' grapevine rootstock. Revista Brasileira de Fruticultura, Jaboticabal, v.24, n.3, p.759-764, 2002. Available from: <http://www.scielo.br/pdf/ rbf/v24n3/15134.pdf $>$. Accessed: Feb. 18, 2013. doi: 10.1590/ S0100-29452002000300050.
GRATTAPAGLIA, D.; MACHADO, M.A. Micropropagação. In: TORRES, A.C. et al. Cultura de tecidos e transformação genética de plantas. Brasília: EMBRAPA-SPI / EMBRAPACNPH, 1998. p.183-260.

MURASHIGE, T.; SKOOG, F. A revised médium for rapid growth and bioassays with tobacco tissue cultures. Physiologia plantarum, Copenhagem, v.15, p.473-497, 1962

PIERIK, R.L.M. In vitro culture of higher plants. Dordrecht: Martinus Nyhoff, 1987. 344p.

RODRIGUES, A.C. et al. Establishment and multiplication in vitro of Prunus sp. in different culture media. Revista Brasileira de Fruticultura, Jaboticabal, v.25, n.1, p.131-133, 2003. Available from: <http://www.scielo.br/scielo.php?pid=S010029452003000100037\&script $=$ sci_arttext $>$. Accessed: Feb. 18, 2013. doi: 10.1590/S0100-29452003000100037.

SOUZA, J.A. de et al. Effect of the branch type and light regimen provided to the donors-plant in the in vitro establishment of araçazeiro cv. 'Irapuã'. Ciência Rural, Santa Maria, v.36, n.6, p.1920-1922, 2006. Available from: <http://www.scielo.br/pdf/ cr/v36n6/a41v36n6.pdf >. Accessed: Mar. 05, 2013. doi: 10.1590/ S0103-84782006000600041.

VILLA, F.etal.In vitro blackberry growing: effect of growth regulators andcultivar. CiênciaeAgrotecnologia,Lavras,v.32,n.6,p.1754-1759, 2008. Available from: $<\mathrm{http} / / / w w w . s c i e l o . b r / s c i e l o . p h p ? s c r i p t=s c i$ arttext\&pid $=$ S $141370542008000600012 \& \operatorname{lng}=$ en \&nrm $=$ iso $>$. Accessed: Mar. 17, 2013. doi: 10.1590/S1413-70542008000600012. 